\title{
Application of Induced Polarization and Resistivity to the Determination of the Location of Metalliferous Veins in the Taroucht and Tabesbaste Areas (Eastern Anti-Atlas, Morocco)
}

\author{
Ibrahim Dakir $(\mathbb{D}){ }^{1}$ Ahmed Benamara, ${ }^{2}$ Habiba Aassoumi, \\ Abdessalam Ouallali $\mathbb{D},{ }^{1}$ and Youssef Ait Bahammou ${ }^{3}$ \\ ${ }^{1}$ Cartography and Digital Technologies, Department of Geology, Faculty of Science, Abdelmalek Essaadi University, Tetouan, Morocco \\ ${ }^{2}$ Applied Geophysics and Modeling in Geoenvironment, Department of Geology, Faculty of Science and Techniques, \\ Moulay Ismail University, Errachidia, Morocco \\ ${ }^{3}$ Laboratory of Geophysics and Natural Risks, Department of Geology, Faculty of Sciences, Mohammed V University, Rabat, Morocco
}

Correspondence should be addressed to Ibrahim Dakir; dakiribrahim@gmail.com

Received 5 January 2019; Revised 6 May 2019; Accepted 4 June 2019; Published 7 July 2019

Academic Editor: Pantelis Soupios

Copyright (c) 2019 Ibrahim Dakir et al. This is an open access article distributed under the Creative Commons Attribution License, which permits unrestricted use, distribution, and reproduction in any medium, provided the original work is properly cited.

\begin{abstract}
The study area is located in the extreme southwest of the Ougnat Mountains in the eastern Anti-Atlas, which is part of the distorted northern margin of the West African craton. It has Late Neoproterozoic to terminal, Paleozoic and Quaternary lands. In order to obtain a better recognition of the different structural contacts and to define the alignment of mineralized veins in barite and galena at the level of the study area, we used the technique of electrical tomography. The resulting response, in the form of electrical imaging, informed us in detail about the different zones of heterogeneity existing in the prospected soil. In induced polarization, the pseudosections obtained were able to locate the passages of the zones of anomalies encountered and thus confirm their alignments defined by the electrical resistivity measurement results.
\end{abstract}

\section{Introduction}

The Taroucht area is located south of the town of Tinejdad (southeast of Morocco). It begins with the complete localities of Tin Ayt Mhemd, Ihendar, Taghya, and ends with the great mountainous region which is a part of the great fault which elongates the palaeozoic formations to the town of Banigounssa in the southwest.

In order to obtain a better recognition of the different structural contacts and to define the alignment of the mineralized veins in this zone, we used the geophysical investigation technique.

The measurement procedure consists of the introduction of electrical tomography at the localities of Taroucht and Tabesbaste, whose objective is to highlight an image of the subsoil according to sections of electrical resistivity. In order to confirm the location of the different contacts encountered, we also provided measurements in induced polarization (IP). This imagery gives detailed information on the different heterogeneities existing within the prospected field. The depth of the ground prospected by the measurement profiles is around $54 \mathrm{~m}$ approximately. Electrical resistivity tomography is a geophysical tool used in geological, mining prospecting, hydrological, and geotechnical investigations. Resistivity and induced polarization profile lines were carried out with Wenner array. Resistivity and chargeability are well known geophysical methods and are traditionally applied to mineral exploration; see the studies by Bérubé P. [1], Djroh S. P. [2], and Nicolas F. et al. [3], and, in environmental studies, they are often used to delineate contaminant plumes and geological boundaries; see, for example, the studies by Vagner Roberto Elis et al. [4], Aristodemou and Thomas-Betts [5], Baines et al. [6], Bernstone et al. [7], BLONDEL [8], and HACINI et al. [9]. According to Johansson et al. [10], the combination of resistivity and time domain induced polarization (IP) can improve the use of geoelectrical methods in landfill investigation. 


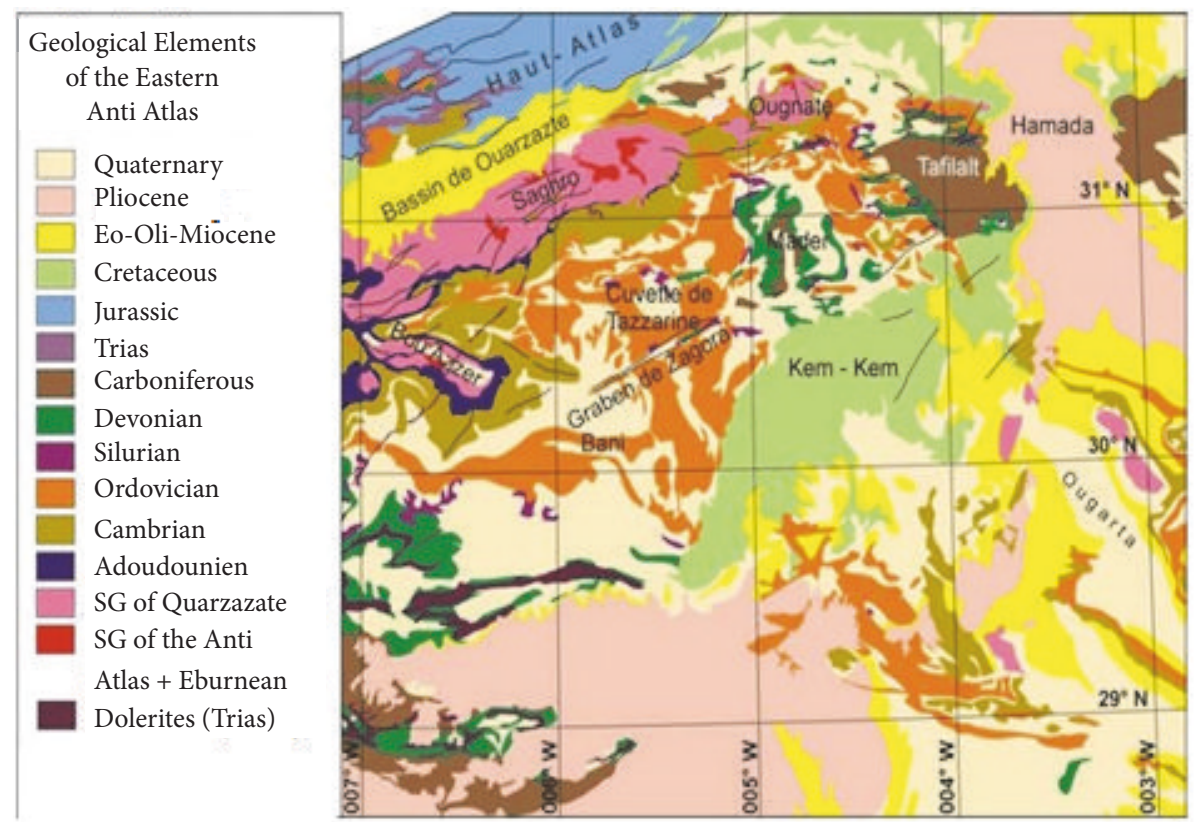

FIgURE 1: Geological elements of the Anti-Atlas of the East. According to the geological map 1/1,000,000 of Morocco (1985).

Given the configuration of the prospected area which is very rugged and given its quality which is strongly fractured, the coupling between these two techniques, electrical resistivity and induced polarization, seems essential. Indeed, the contribution of the chargeability response makes it possible both to confirm the results of the response of the electrical resistivity at the level of the ground prospected and also to distinguish these results from those relating to the clay materials which accumulate in fractures. The fractured zones are the seat of the very frequent flows of water disturbing the exploitation of the deposit in place. In calcareous medium and in sandstone environment, the prospection by chargeability seems better compared to that of the other methods (for example, the electromagnetic technique), and the signal obtained provides contrasts well individualized and easily interpretable at the meeting of the mineralized zones. It should be noted that, for metallic particles, there is a perfect correlation between the response of the resistivity signals and that of the IP signals [11].

\section{Geological and Morphostructural Context of the Ougnat Massif}

2.1. Geological Context. The Ougnat buttonhole is part of the Eastern Anti-Atlas and represents the continuity towards the Northeast of the Saghro Range whose lands are of Neoproterozoic age (Figure 1). It is characterized by the presence of a lower Neoproterozoic base formed essentially of a volcanic-sedimentary series in oriented strips NNE-SSW [12]. The latter is intruded by small masses of quartz diorite and granodiorite which in turn are intruded by a garnet granite. According to Abia [12] and Abia et al. [13], Ougnat granitoids are organized into two geochemically different units of different origins: the Ougnat rhyolitic complex and the Ougnat pyroclastic complex.
The base appears as buttonholes, from west to east, the buttonhole of Saghro and that of Ougnat, with its ENE-WSW orientation. The folding of the palaeozoic cover is enhanced by the formation of the Bani; Ordovician ridge is visible virtually throughout the Anti-Atlas. The large-scale image of the Paleozoic shows a series of domes and basins. It is represented, from West to East, by the basin of Tazzarine and the basins of Maïder and Tafilalet [14].

The lithostratigraphic series of the study area (Figure 2) is based mainly on the geological map of Morocco (Tourach leaf at $1: 50,000,[15])$ and on some observations that we made during our field visit.

2.2. Structural Overview of the Anti-Atlas. The structuring of this region was carried out in the lower paleozoic and then during the hercynian cycle. It is the hinterland of the hercynian orogeny. Thus, the formations of the study area are characterized by a set of faults of direction generally EW to NE-SW inherited from the rifting periods (CambroOrdovician; Devon middle-upper) and which have been reactivated in inversion during the rifting period hercynian orogeny. The corresponding rejections in inversions or inverse weaknesses are at the origin of the generally open folds that occur in the palaeozoic cover of the massif [16]. The map of Figure 3 also illustrates the contours of the isobaths (equal depth curve of the base) which are sometimes offset by the faults; the further away from the buttonhole, the greater the depth of the base.

The section of Figure 4 shows the different structural contacts and the geological formations encountered in the Taghoucht zone.

\section{Equipment and Methods}

The induced polarization (IP) method is based on a currentstimulated electrical phenomenon observed as a delayed 


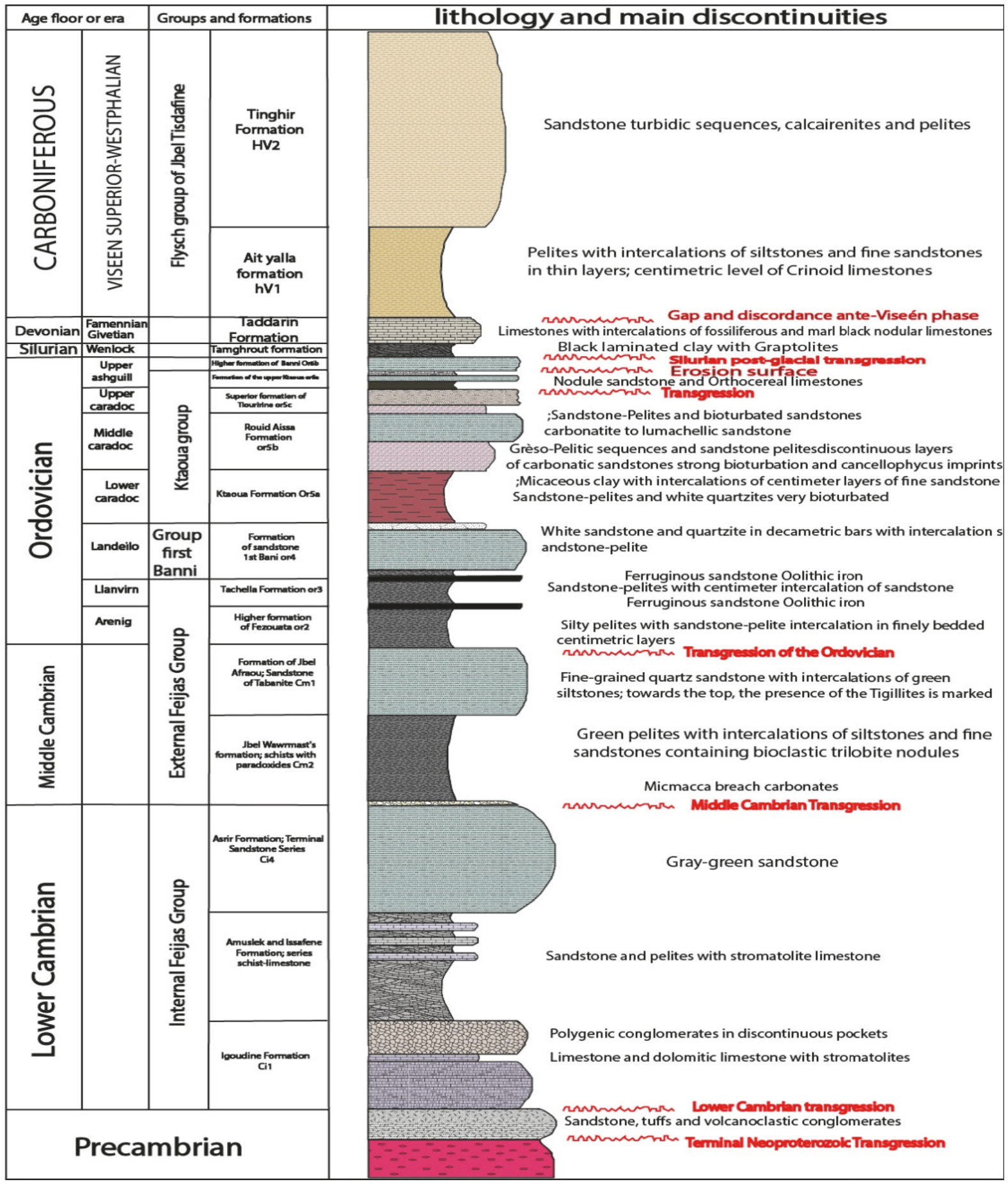

FIgURE 2: Stratigraphic Log of the study area.

voltage response in earth materials. The IP effect is observed as a residual voltage decay after the current flow is interrupted (time domain IP) or as a frequency-dependent resistivity (frequency domain). In the time domain, the voltage decay is recorded during a time interval $\Delta t=t_{2}-t_{1}(m s)$ after the current flow is interrupted. The calculated parameter is the chargeability, given by

$$
m=\frac{1}{V_{0}} \int_{a}^{b} V_{t}(t) d t
$$

The first step in interpreting data in electrical tomography is to construct a pseudosection. This is obtained by plotting the value of the apparent resistivity measured at the center of the array and at a depth dependent on the spacing between the electrodes (Edwards, 1997).

The data was inverted by the Res2Dinv software using the robust inversion L1 [17, 18] (Figure 5).

The acquisition was made by the ABEM Terameter SAS menu of 64 electrodes placed at intervals of $5 \mathrm{~m}$; the length of each profile is $320 \mathrm{~m}$ (Figure 6). 


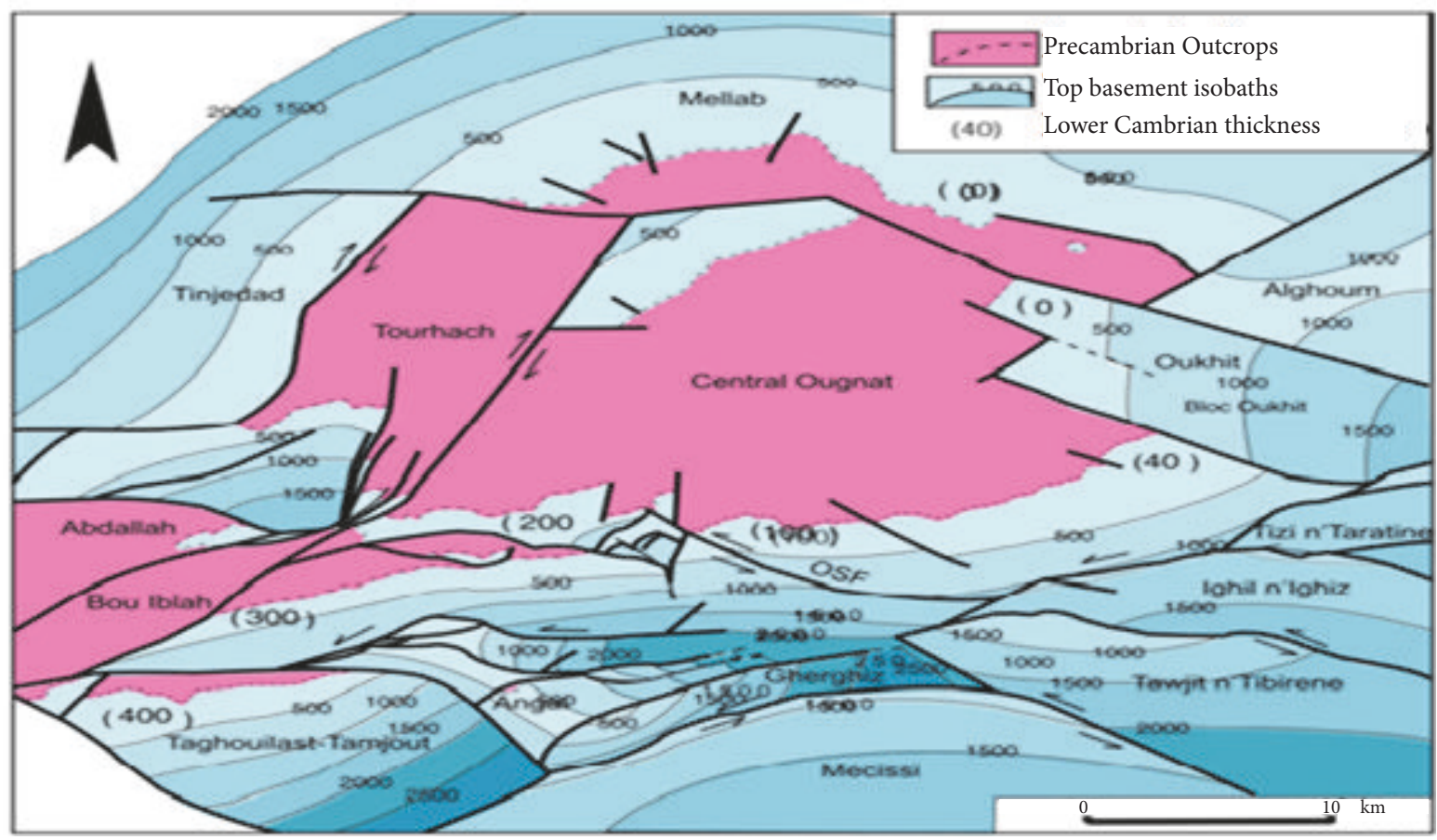

FIGURE 3: General structural scheme of the Eastern Anti-Atlas.

NNE

SSW
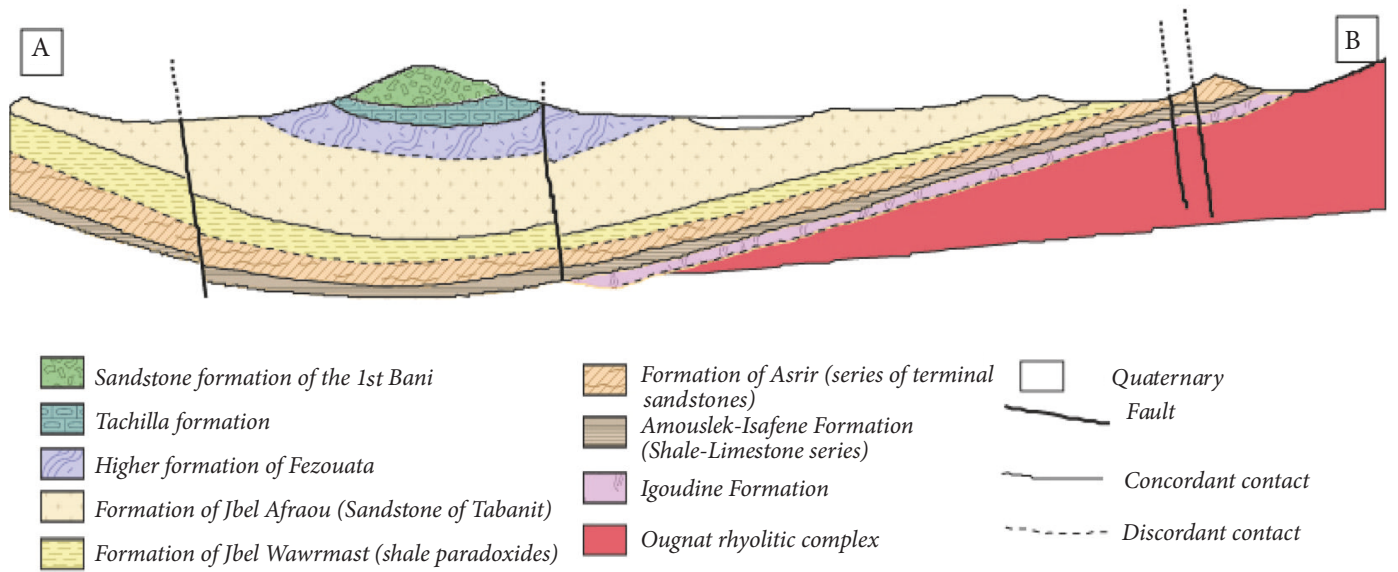

FIGURE 4: Synthetic geological section made in the area of Taroucht.

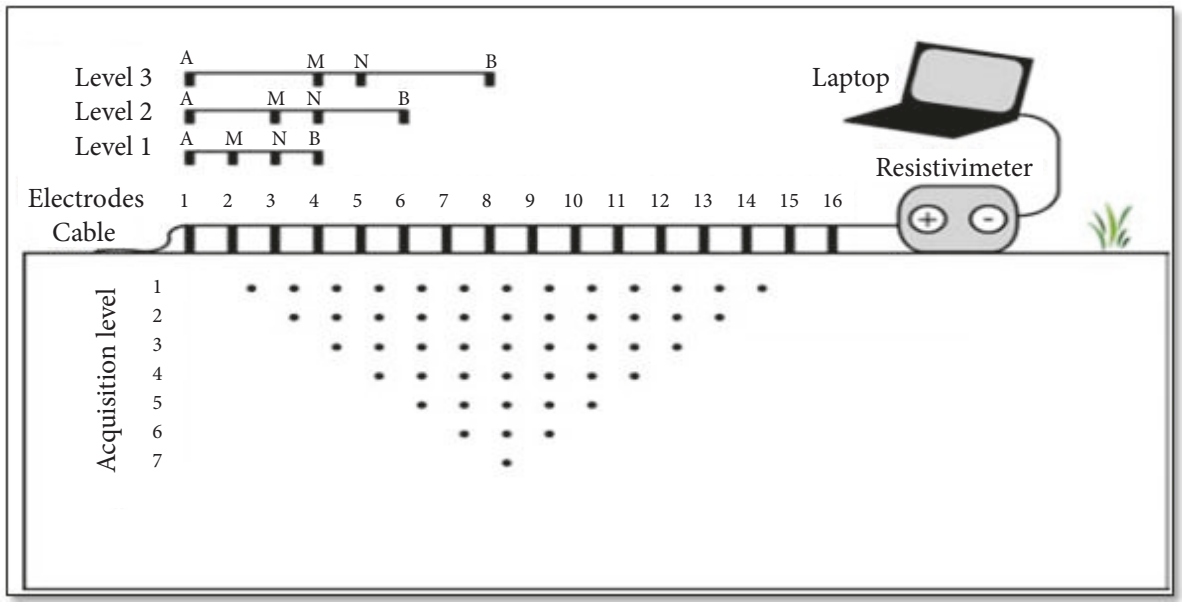

FIGURE 5: Implementation of 2D electric tomography (Edwards, 1997). 


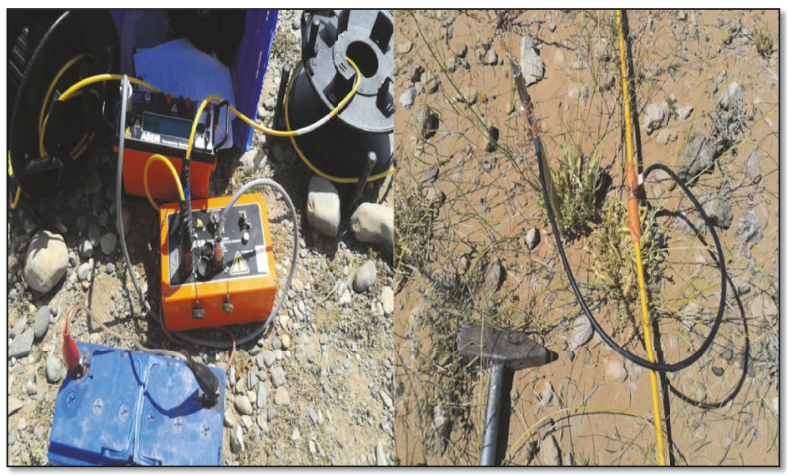

FIGURE 6: Instruments for the measurement of tomography.

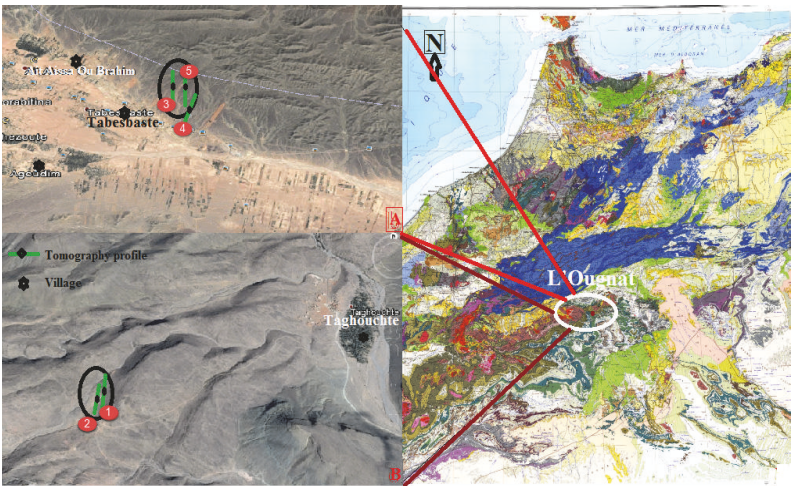

Figure 7: Location of the study area: A, Tabesbaste area; B, Taroucht area.

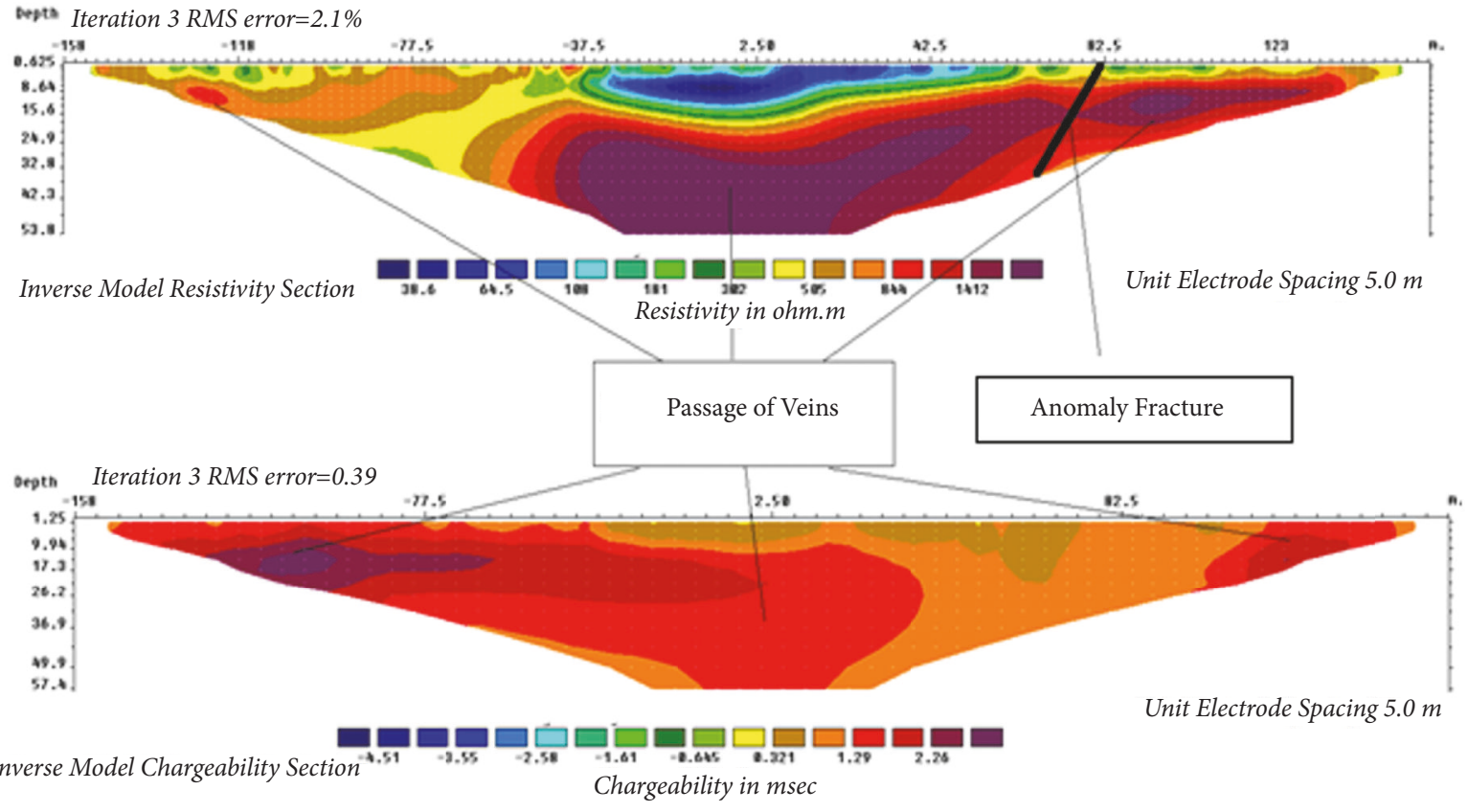

FIGURE 8: Inverse model resistivity and chargeability sections (Taroucht 1; direction: SSE-NNW). 


\section{SSE}

NNW
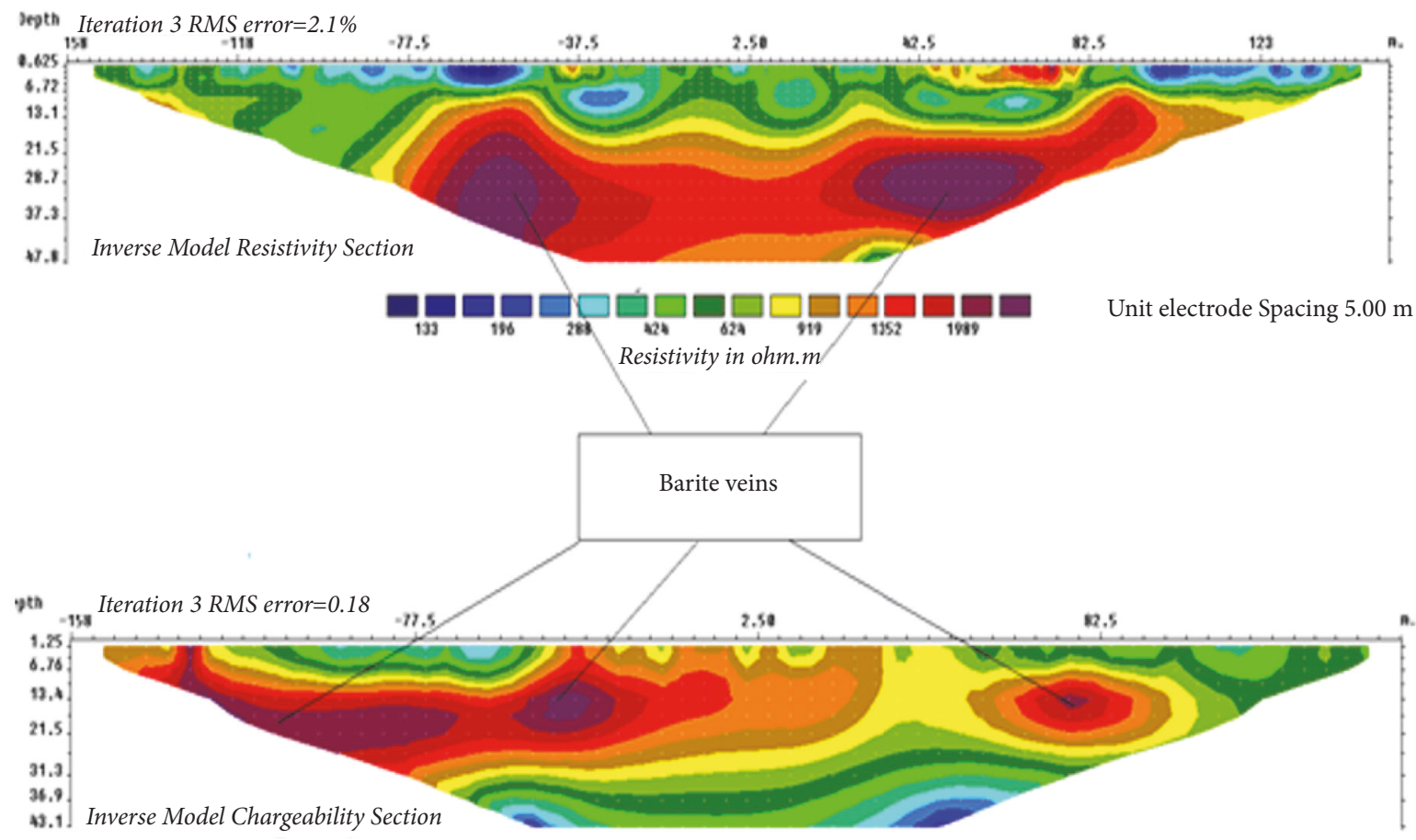

0.138

FIGURE 9: Inverse model resistivity and chargeability sections (Taroucht 2; direction: SSE-NNW).

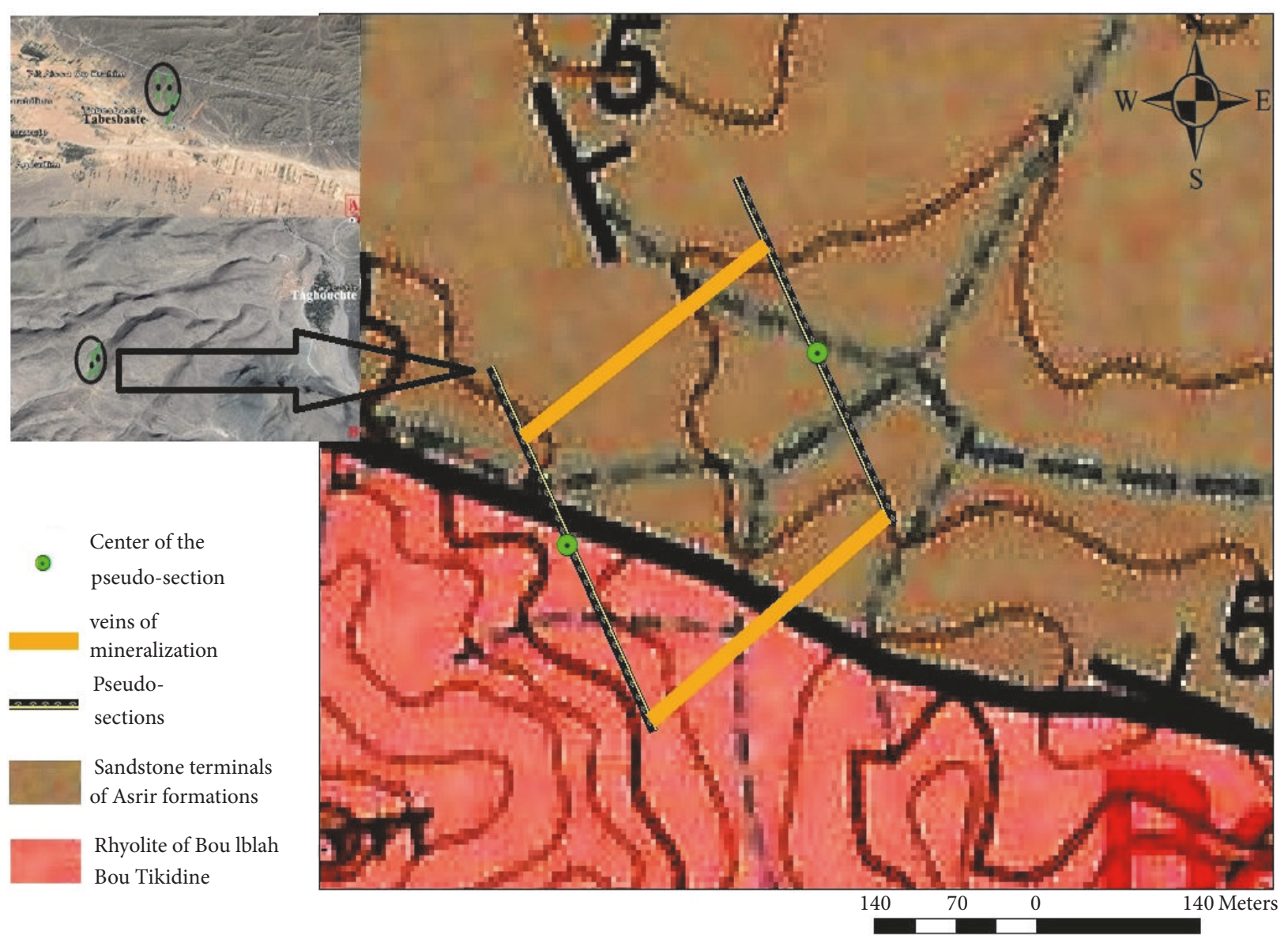

FIGURE 10: Map of correlation of the barite veins obtained by pseudosections 1 and 2 (extracted from the Morocco Taroucht geological map 1/50000). 


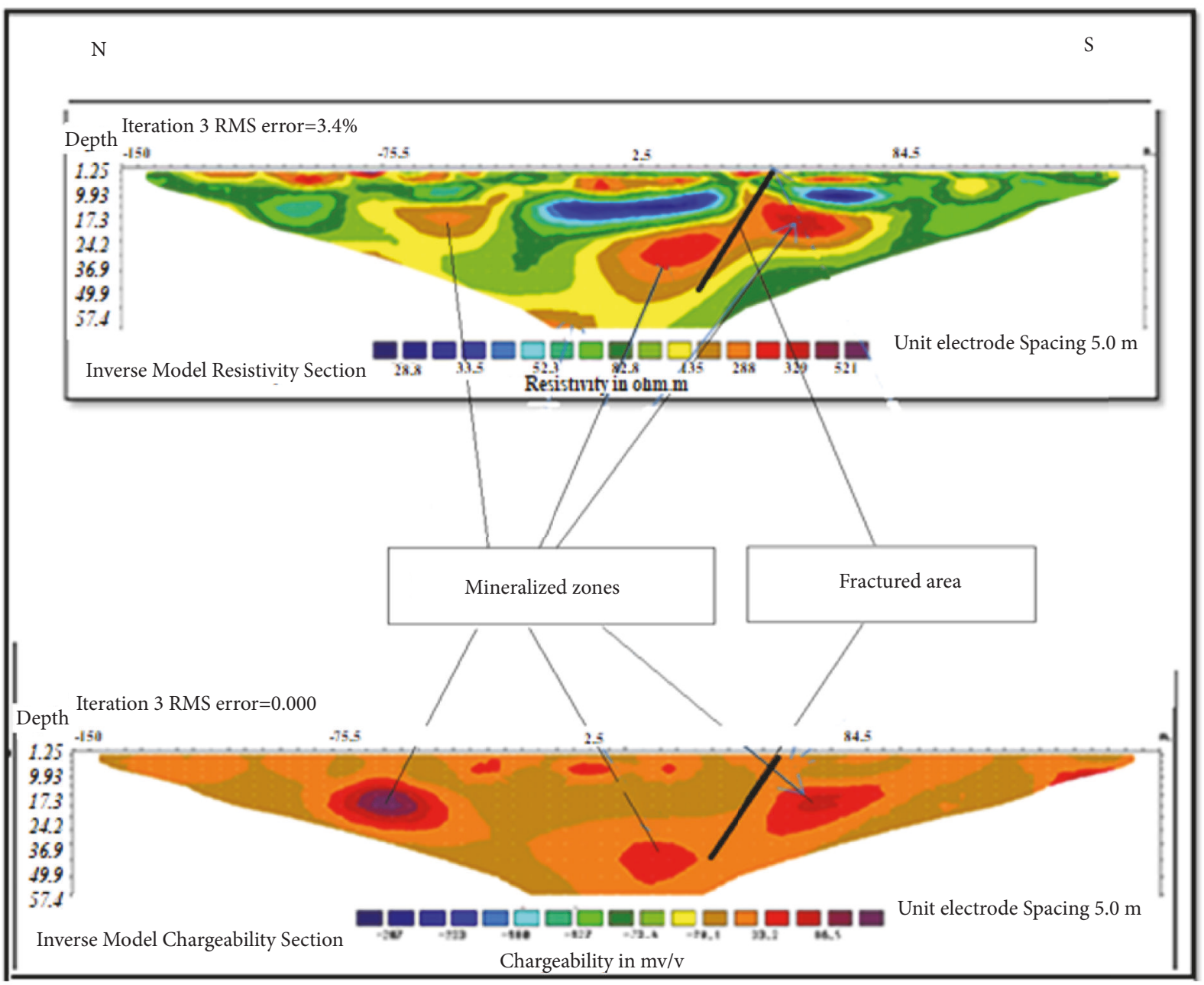

FIGURE 11: Inverse model resistivity and chargeability sections (Tabesbaste 1; direction: N-S).

\section{Results and Discussion}

In order to obtain a better recognition of the spatial quality of the studied site, we used the technique of electrical tomography, which allows to provide an electrical image of the subsoil, combining both the resistivity response and that of the chargeability based on depth. This electrical imaging provides us with more detailed information on the location of the mineralized zones, on the one hand, and on the determination of the heterogeneity of the ground prospected on the other hand.

Indeed, five profiles in Wenner electric tomography have been realized. Two profiles were made at the sandstone and limestone stromatolite formations of Lower Cambrian age in the western part of Taroucht village, to detect the mineralized barite veins, and the three others are made at the Silurian age shale formations, in the locality of Tabesbaste, whose aim is to follow the alignment of the mineralized veins in galena (Figure 7).

4.1. Results Obtained in Taroucht Area. Profile 1 is executed to the west of the village of Taghoucht, and it is manufactured in the direction of SSE-NNW, in the coordinates of Lambert X $=534792.65 \mathrm{~m}, \mathrm{Y}=86595.67$, and $\mathrm{Z}=1166 \mathrm{~m}$.

The result of this profile (Figure 8 ) shows the presence of two mineralized zones:

(i) The first zone is located in the SSE part at a distance of $40 \mathrm{~m}$ from the beginning of the profile (at a depth of approximately $15 \mathrm{~m}$ ), its chargeability value exceeds 4 $\mathrm{msec}$, and its resistivity is around $850 \mathrm{Ohm}-\mathrm{m}$.

(ii) The 2 nd vein seems cut by a fracture anomaly. It is close to the surface at the NNW portion and sinks deep in the middle of the pseudosection (about $25 \mathrm{~m}$ ). Its chargeability is around $2.6 \mathrm{msec}$ and its resistivity exceeds $1600 \mathrm{Ohm}-\mathrm{m}$, and this vein is very thick on the order of $5 \mathrm{~m}$ in the deep.

(iii) The passage of another mineralized vein was not detected by the resistivity profile, but it is well evidenced by the chargeability response in the SSE part of the profile.

The lands that mask the mineralized zone at depth correspond to fissured sandstone formations covered with colluvium accumulating high humidity. 


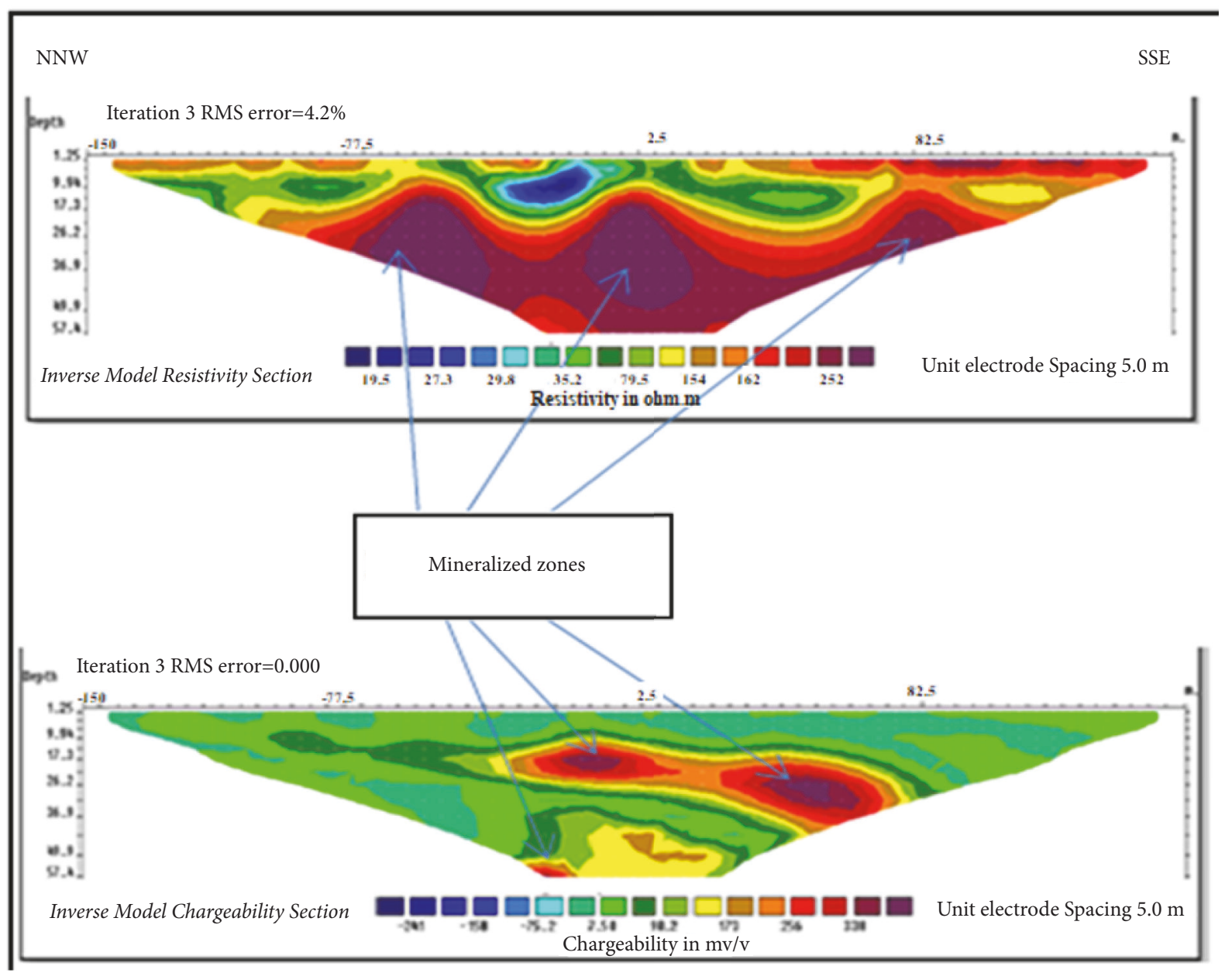

FIGURE 12: Inverse model resistivity and chargeability sections (Tabesbaste 2; direction: NNW-SSE).

In the middle of the ground prospected, there is the presence of a very wet colluvium accumulation zone; the value of the resistivity is of the order of $60 \mathrm{ohm}-\mathrm{m}$.

It should also be noted that this profile intersects an E-W fracture zone.

Profile 2 was made at a distance of $200 \mathrm{~m}$ East of the first profile in direction NNW-SSE and in coordinates Lambert X $=534577.38 \mathrm{~m}, \mathrm{Y}=86442.72 \mathrm{~m}$, and $\mathrm{Z}=1340 \mathrm{~m}$.

The pseudosections obtained (Figure 9) highlight three mineralized zones:

(i) The first zone is located at about $35 \mathrm{~m}$ from the beginning of the ground prospected and corresponds to the passage of a seam flush on the surface and becomes wider and inclined in depth. Its chargeability value is around $5 \mathrm{msec}$.

(ii) The second is located almost in the middle of the profile, at a depth of $20 \mathrm{~m}$ and chargeability of the order of $2.5 \mathrm{msec}$.

(iii) The third zone is marked towards the NNW part at a distance of $240 \mathrm{~m}$ from the beginning of the profile. Its depth is almost the same as in the first case and its resistivity exceeds $1500 \mathrm{Ohm}$-m.
The orientation of the electrical tomography profiles is selected according to the direction of the vein portions observed at the outcrop. Indeed, according to Figure 10 the mineralization is generally oriented NE-SW.

Profile one crosses the two formations (lower Cambrian Asrir sandstone and Neoproterozoic age rhyolitic tuffs). This profile suggests the presence of two veins: the first is located in the southern part and the second at the end of the pseudosection. Profile 2 is made in the sandstone formation, and it shows the presence of the same mineralized veins.

The correlation between the two pseudosections (Figure 10) indicates the presence of continuity between the two detected veins:

(i) For the lode identified in the southern part, the response of the chargeability signal is important in rhyolitic formations ( $2 \mathrm{~m}$ thick), and this lode sinks deeply in the second profile under the sandstone formations in place which cover both the vein and rhyolitic volcano-sedimentary tuffs.

(ii) Concerning the vein of the North part, the answer of the chargeability is almost identical in the two pseudosections, and this vein is met with a relatively 


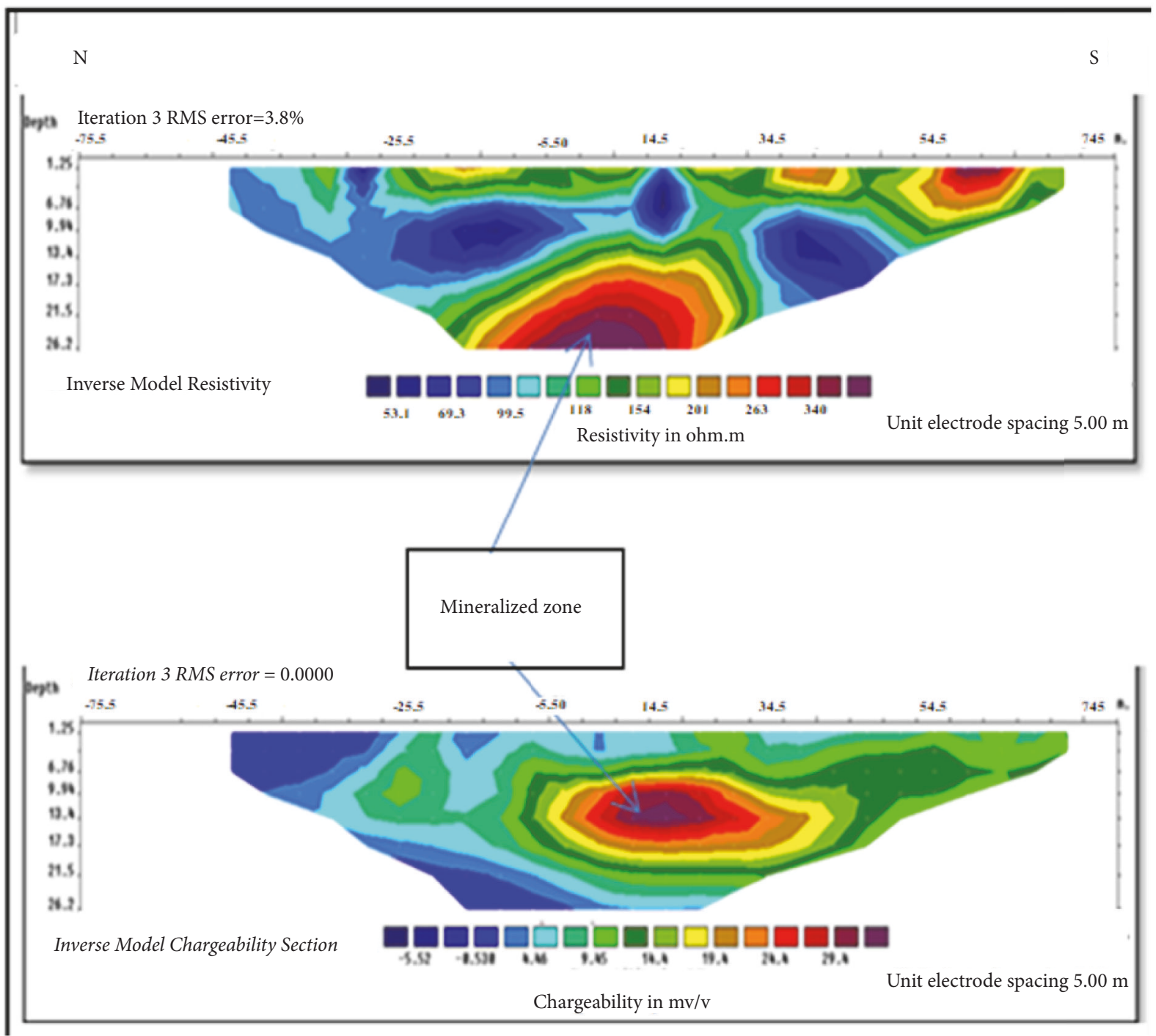

FIGURE 13: Inverse model resistivity and chargeability sections (Tabesbaste 3; direction: N-S).

constant depth (of the order of 20m) and developed on a thickness which reaches $3 \mathrm{~m}$.

4.2. Results Obtained in Tabesbaste Area. Indeed, three profiles in electrical tomography have been made in this locality.

Profile 3 (Figure 11) is located in the vicinity of the right bank of the National Road No. 10 connecting the two cities Tinejdad and Tinghir. The prospected field has a SSWNNE direction in Lambert $\mathrm{X}$ coordinates $=504182.89, \mathrm{Y}=$ 96448.01m, and $\mathrm{Z}=1174 \mathrm{~m}$.

At this locality, the model obtained shows large heterogeneities with significant contrasts, and the values attributed to the passages of the mineralized zones differ considerably from those corresponding to the surrounding lands (shale). Thus, the pseudosection established (Figure 11) highlights a mineralized zone identified at $85 \mathrm{~m}$ from the beginning of the profile, whose apex is located at about $10 \mathrm{~m}$ and its chargeability value exceeds $100 \mathrm{msec}$.
Another relatively mineralized zone is located in the middle of the profile $(80 \mathrm{msec})$. The latter appears cut and associated with a passage of a fracking anomaly zone (direction SSE-NNW), whose resistivity is of the order of 130 ohm-m.

In addition to these zones of anomalies, this profile also shows zones of accumulation of water, and they are located on both sides of the location of the area of fracturing anomaly.

Profile 4 is made in the vicinity of Profile No. 3; it is made in the NNW-SSE direction and Lambert X coordinates $=504294.00 \mathrm{~m}, \mathrm{Y}=96228.38 \mathrm{~m}$, and $\mathrm{Z}=1173 \mathrm{~m}$.

For the resistivity response, the resulting pseudosection (Figure 12) highlights two mineralized zones:

(i) The first is shallow and located in the middle of the profile at a depth of approximately $20 \mathrm{~m}$, but which sinks deeply towards the South-East part.

(ii) The second zone is also announced in the middle of the profile, but it is deeper. Its summit is close to a depth of about $50 \mathrm{~m}$. 


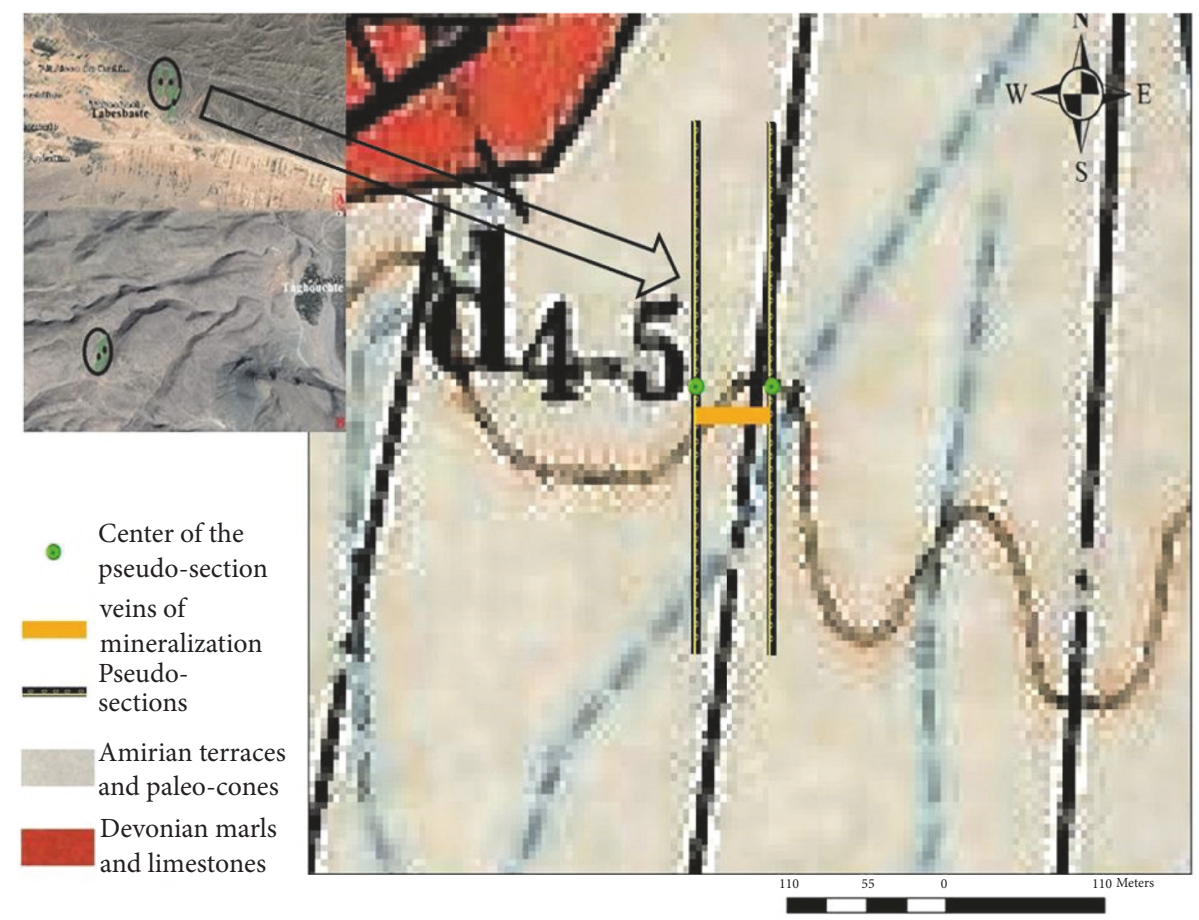

Figure 14: Map of correlation of the Galena veins obtained by pseudosections 3 and 5 (extracted from the Morocco Taghazout geological map 1/50000).

Regarding the chargeability result, we can say that it is a single mineralized passage but well inclined while sinking towards the SE direction. Its load value exceeds $400 \mathrm{msec}$. The profile announces another deep mineralized zone, but it is less individualized.It should also be noted that this profile intersects a fracture zone clearly visible topographically and oriented slightly N-S.

Profile 5 is made in the N-S direction, in Lambert $\mathrm{X}$ coordinates $=504236.30 \mathrm{~m}, \mathrm{Y}=96448.01$, and $\mathrm{Z}=1161 \mathrm{~m}$.

The results of the profile (Figure 13) show a slightly mineralized structure in the middle of the ground prospected, located at a depth of the order of $15 \mathrm{~m}$. Its resistivity is of the order of $350 \mathrm{ohm}-\mathrm{m}$ and its chargeability is around $35 \mathrm{msec}$. This vein is well individualized in depth which reaches $3 \mathrm{~m}$ thick.

According to Figure 14, electrical tomography profiles have been performed in recent quaternary formations.

The correlative study of the profiles carried out suggests the continuity of the vein 3 which becomes more important ( $3 \mathrm{~m}$ thick) at the level of the pseudosection 5. Indeed, the general direction of the veins is oriented E-W.

The other two veins identified by Profile 3 are absent in Profile 5; this absence is explained by 2 hypotheses:

(i) Their deep penetration, knowing that the pseudosection obtained at their level does not exceed a depth of $26 \mathrm{~m}$

(ii) The three veins that are joined in Profile 5; that is why one records a thickening of the latter $(3 \mathrm{~m})$ and the answer of the signal obtained at its level is relatively more important.

\section{Conclusion and Perspectives}

The prospection in electrical tomography carried out at these two localities, Taroucht and Tabesbaste, made it possible to provide information on the different heterogeneities present in the surrounding lands prospected, in this case the Paleozoic formations (sandstone and sandstone limestone). Indeed, it was able to highlight the location and alignment of the mineralized veins.

In the vicinity of the Taroucht area, the comparison between the pseudosection models obtained from the chargeability and those obtained from the resistivity made it possible to locate important zones of anomalies attributed in particular to the location of the baryte veins (BaSO4). Indeed, the passage of the mineralized zones presents important values of the two parameters (resistivity and chargeability); this comes from the fact that the veins are cashed at the level of the most compact parts of the surrounding land; these zones are sometimes raised with respect to the rest. The land seems more altered on both sides of the passage of these veins, sometimes presenting conductive clay intercalations.

It should be noted that the chargeability values obtained at Tabesbaste are higher compared to those obtained at Taroucht; they exceed $100 \mathrm{msec}$ while they are less than 10 msec in Taroucht.

Given the importance of the results obtained in these areas prospected, it is therefore necessary to enrich them by the achievement of other profiles by providing mainly measurements in electromagnetic trails in order to identify the various heterogeneities and their relationship with the veins, on the one hand, and to characterize in a 
more detailed way their mineral potentiality on the other hand.

\section{Data Availability}

The data used to support the findings of this study are available from the corresponding author upon request.

\section{Disclosure}

This research did not receive any financial support.

\section{Conflicts of Interest}

No potential conflicts of interest were reported by the authors.

\section{References}

[1] P. Bérubé, Résistivité/Polarisation Provoquée en Exploration Minière, Rapp. VAL D'OR SAGAX INC., Canada, 1997.

[2] S. P. Djroh, Etudes géophysiques du gisement cupronickelifère à platinoïde de Samapleu. Essai de modélisation 3D par interprétation des données magnétiques et électriques [doctoral thesis], Univ. Félix Houphouët-Boigny, Côte d'Ivoire, 2014.

[3] N. Florsch, A. Feras, J. Bonnenfant, and C. Camerlynck, "La polarisation provoquée, outil géophysique de spatialisation des amas de scories pour lestimation des productions sidérurgiques," ArcheoSciences, vol. 2, no. 41-42, pp. 23-33, 2017.

[4] V. R. Elis, A. T. Ustra, M. C. Hidalgo-Gato, O. J. Pejon, and F. Y. Hiodo, "Application of induced polarization and resistivity to the environmental investigation of an old waste disposal area," Journal of Environmental Earth Sciences, vol. 75, no. 20, article 1338, 2016.

[5] E. Aristodemou and A. Thomas-Betts, "DC resistivity and induced polarisation investigations at a waste disposal site and its environments," Journal of Applied Geophysics, vol. 44, no. 2-3, pp. 275-302, 2000.

[6] D. Baines, D. G. Smith, D. G. Froese, P. Bauman, and G. Nimeck, "Electrical resistivity ground imaging (ERGI): a new tool for mapping the lithology and geometry of channel-belts and valley-fills," Sedimentology, vol. 49, no. 3, pp. 441-449, 2002.

[7] C. Bernstone, T. Dahlin, T. Ohlsson, and H. Hogland, "DCresistivity mapping of internal landfill structures: two preexcavation surveys," Environmental Geology, vol. 39, no. 3-4, pp. 360-371, 2000.

[8] A. Blondel, Développement des méthodes géophysiques électriques pour la caractérisation des sites et sols pollués aux hydrocarbures [doctoral thesis], de l'université Michel de Montaigne, 2014.

[9] Y. Hacini, L. Marescot, and D. Chapellier, "Constraints in hydrogeophysical $2 \mathrm{~d}$ resistivity imaging. case history: kappelen test site," in Proceedings of the 11the European Meeting of Environmental and Engineering Geophysics, Palermo, Italy, 2005.

[10] B. Johansson, S. Jones, T. Dahlin, and P. Flyhammar, "Comparisons of $2 \mathrm{D}$ - and $3 \mathrm{D}$-inverted resistivity data as well as of resistivity- and IP-surveys on a landfill," in Proceedings of the 13th European Meeting of Environmental and Engineering Geophysics of the Near Surface Geoscience Division of EAGE, Near Surface 2007, Istanbul, Turkey, September 2007.
[11] D. Mao, A. Revil, and J. Hinton, "Induced polarization response of porous media with metallic particles - part 4: detection of metallic and nonmetallic targets in time-domain induced polarization tomography," Geophysics, vol. 81, no. 4, pp. D359D375, 2016.

[12] E. H. Abia, Cartographie, pétrographie et métallogénie du Protérozoïque du district $\mathrm{Pb}, \mathrm{Zn}, \mathrm{Cu}$ et $\mathrm{Ba}$ de Mellab (massif de l'Ougnat, Anti-Atlas, Maroc), Third Cycle Thesis, Marrakech University, Morocco, 1991.

[13] E. H. Abia, M. Y. Chouhaidi, and H. Nachit, "Plutonisme et relations structuro-métamorphiques panafricaines de la boutonnière de l'Ougnat (Anti-Atlas oriental, Maroc)," in Réunion extraordinaire de la Société géologique de France, Marrakech, Morocco, 1995.

[14] C. H. Robert-Charrue, Géologie structurale de l'Anti-Atlas oriental, Maroc [doctoral thesis], Université de Neuchâtel, 2006.

[15] P. Dainelli et al., DIR. GEOL. MAROC. Carte Géologique du Maroc au 1/50.000, feuille Taroucht- Notice explicative. Notes et Mém. Serv. Géol. Maroc NH-30-XIX-2d, 2007.

[16] L. Baidder, A. Michard, and O. Saddiqi, "Nouveaux guides géologiques et miniers du Maroc/New geological and mining guidebooks of Morocco," Notes et Mémoires du Service Géologique, vol. 2, pp. 47-111, 2011.

[17] M. H. Loke and R. D. Barker, "Rapid least-squares inversion of apparent resistivity pseudosections by a quasi-Newton method," Geophysical Prospecting, vol. 44, no. 1, pp. 131-152, 1996.

[18] M. Loke and T. Dahlin, "Resolution of 2D Wenner resistivity imaging asassessed by numerical modeling," Journal of Applied Geophysics, vol. 38, pp. 237-248, 1998. 

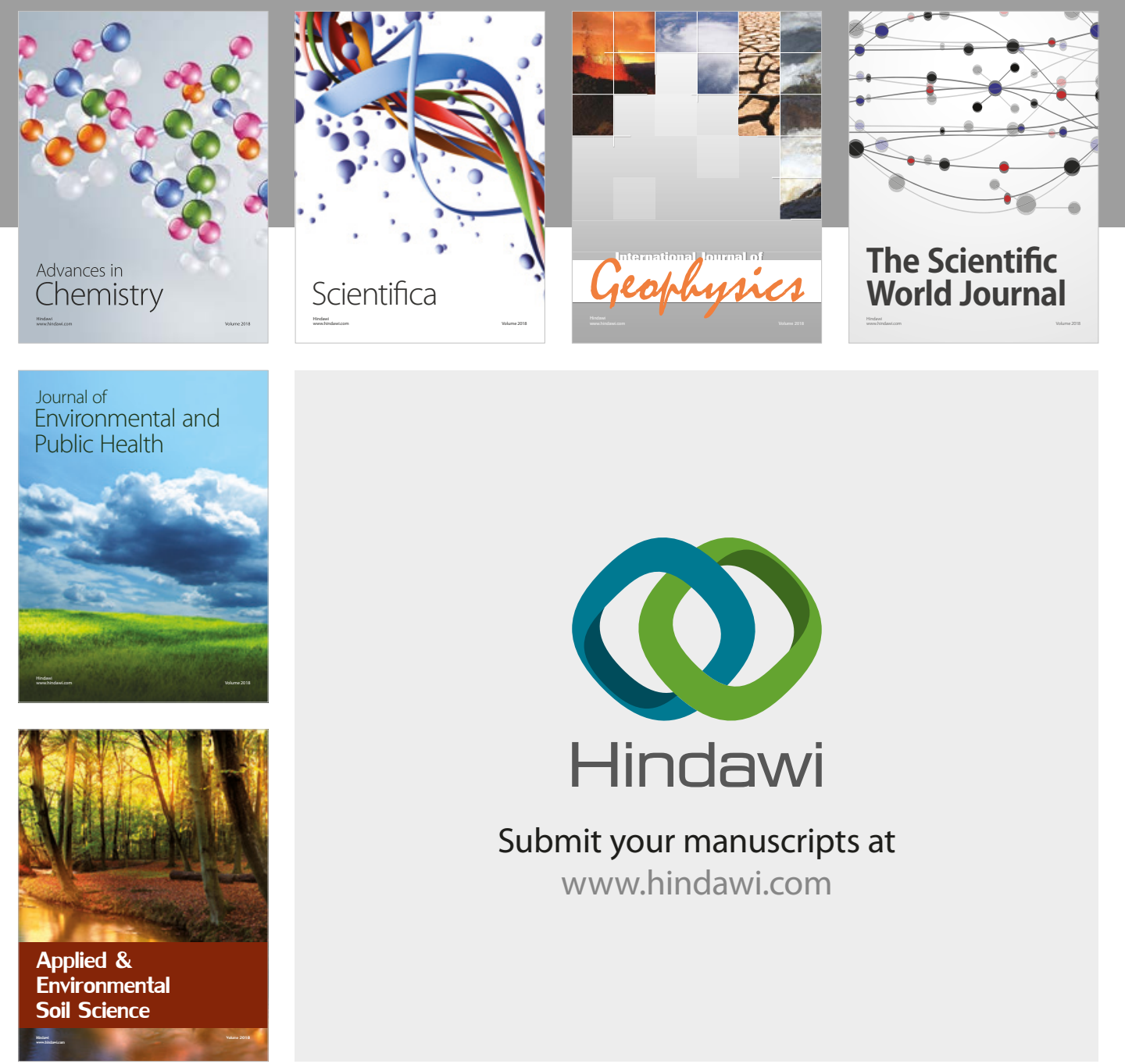

The Scientific

\section{World Journal}
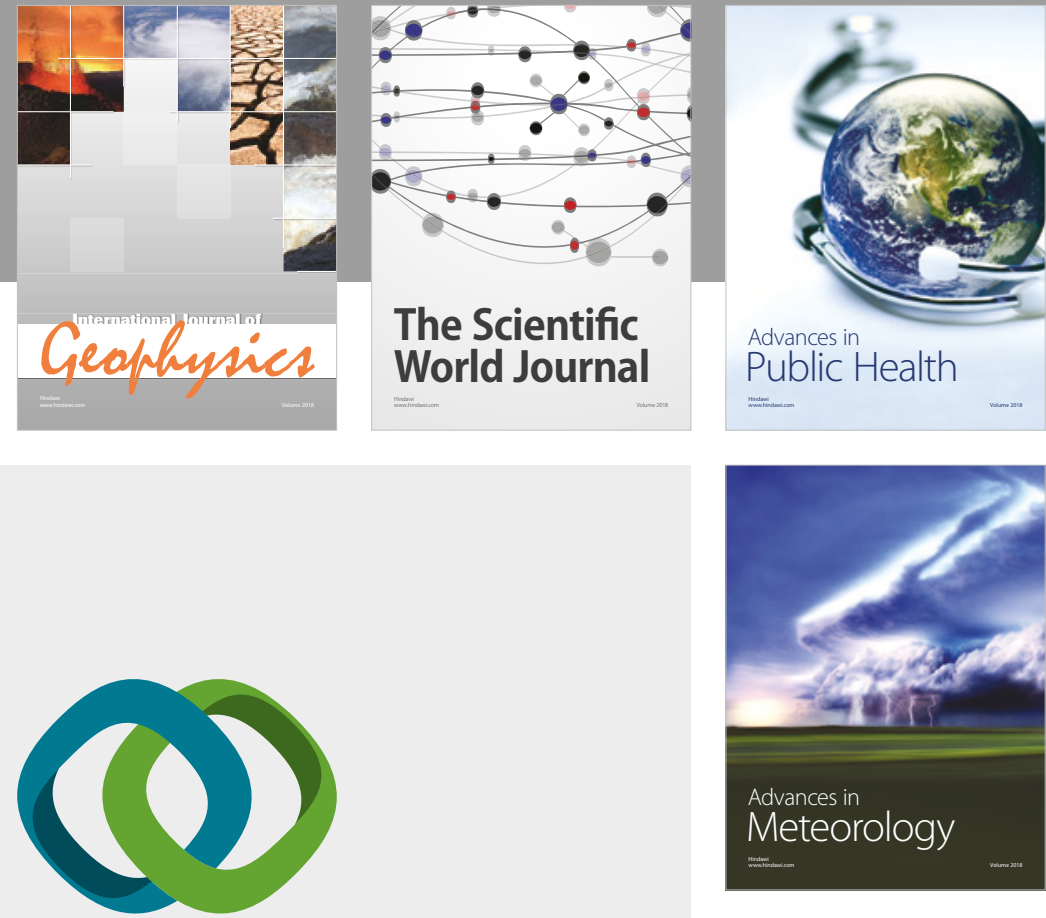

Advan

Public Health

\section{Hindawi}

Submit your manuscripts at

www.hindawi.com
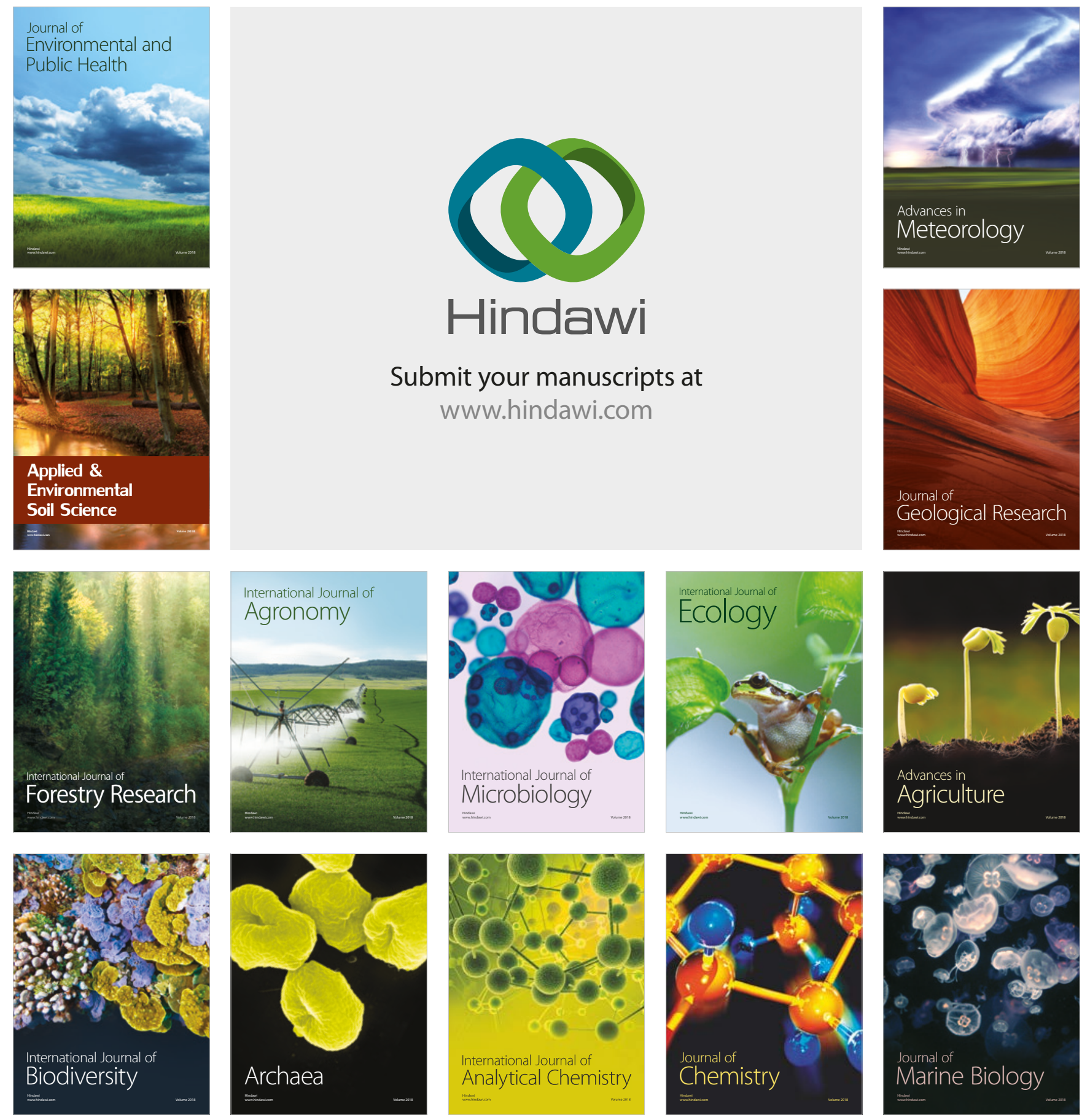